\title{
Returning to 'Representation/s of Women': Feminist analysis and job-sharing as core constitutional concerns
}

\author{
Kim Rubenstein
}

\section{Introduction}

I first met Deborah Cass when I began my undergraduate law studies at the University of Melbourne in 1984, after spending a 'gap year' overseas straight after high school, gathering 'worldly' experiences. We were fellow law students, although she had many more worldly experiences under her belt ${ }^{1}$ and, more significantly through my eyes then, she became well known as one of the editors of the university student newspaper Farrago the following year. When I later became President of the Melbourne University Jewish Students' Society I didn't have much luck enticing Deborah to regular events but we enjoyed stimulating conversations, and

1 Deborah's path to university was different to many at Melbourne law school at that time. She 'attended an experimental school and found its artistic chaos both intoxicating and disturbing. In her mid-teens she rebelled against her upbringing in an unusual way, leaving home to become a secretary and a sales representative living in the outer suburbs. As a result, she got to university five years later than her peers, but determined not to waste any time'. See James Button, 'Writer and Educator Saw Law as a Means to Better the World', Obituary, The Age (Melbourne, 2 August 2013), then published online: James Button, 'Writer and Educator Saw Law as a Means to Better the World', The Sydney Morning Herald (online, 2 August 2013) < https://www.smh.com.au/national/writer-andeducator-saw-law-as-a-means-to-better-the-world-20130801-2r1oj.html>. See a little more about Deborah at: Helen Irving, 'Vale: Deborah Zipporah Cass 15 February 1960', A Woman's Constitution (Blog Post, 22 July 2013) <http://web.archive.org/web/20190501064437/http://blogs.usyd.edu.au/ womansconstitution/2013/07/vale_deborah_zipporah_cass.html>. 
I have clear memories of talking with her while checking out books from the Law library back in the days when it was housed in the University of Melbourne's Old Quadrangle.

We followed similar styled paths to academia - the same year of articles in different law firms with practical work experience added in, before setting upon a professional life in academia. Mine with my graduate work first at Harvard before returning to the University of Melbourne, and Deborah starting at the University of Melbourne sooner and then moving to The Australian National University (ANU) before embarking on her graduate work at Harvard. It was during those early academic years that I reconnected with Deborah through her partnership with Gerry, who became my colleague at the University of Melbourne when Deborah was already up at ANU, and it was when Deborah was at Harvard that our academic collaboration emerged.

Deborah contacted me about joining her to write an article she had begun, as she had too much on her research plate to continue with it on her own. Indeed, it is a theme to which this chapter returns - the importance of shared work as a key to constitutional and societal strength. Deborah sent me a skeleton draft, with a clear structure and premise, of what became 'Representations of Women: Towards a Feminist Analysis of the Australian Constitutional System', and it is around that piece this contribution is based. The article was published in the Adelaide Law Review, ${ }^{2}$ and then later reproduced in a modified manner as a chapter in Helen Irving's edited collection, $A$ Woman's Constitution?, ${ }^{3}$ and then further updated for a comparative constitutional law collection. ${ }^{4}$ I am particularly grateful that Deborah invited me to collaborate with her on that article as it was important to my own public law scholarship around the relationship between the individual and the state. Some of that early thinking and our discussions have been central, too, to my work on citizenship, which grew alongside my work on gender and constitutional issues.

2 Deborah Cass and Kim Rubenstein, 'Representations of Women: Towards a Feminist Analysis of the Australian Constitutional System' (1995) 17 Adelaide Law Review 3.

3 Deborah Cass and Kim Rubenstein, 'From Federation Forward: The Representation of Women in the Australian Constitutional System' in Helen Irving (ed), A Woman's Constitution? Gender and History in the Australian Commonwealth (Hale and Iremonger, 1996) 108. The piece was also extracted in one of the early editions of T Blackshield and G Williams, Australian Constitutional Law and Theory (Federation Press, 1996) 98.

4 Kim Rubenstein and Christabel Richards Neville, 'Australia’s Gendered Constitutional History and Future' in Susan H Williams (ed), Social Difference and Constitutionalism in Pan-Asia (Cambridge University Press, 2014), doi.org/10.1017/cbo9781139567312.015. 
This chapter draws out some of the history around the article itself and the central aspects of that article's thesis. It then extends the discussion about the nature of representation, and the concept of shared representation as a means of improving representative democracy in Australia's constitutional system, by examining the court challenge in the UK in 2015 around their elections when two women, Sarah Cope and Claire Phipps, nominated for election to the UK Parliament on a joint job-sharing basis. Their nomination was declined by the acting returning officer and her decision was ultimately upheld by Justice Wilkie in $R$ (Cope) $v$ Returning Officer for the Basingstoke Parliamentary Constituency ('Cope'). ${ }^{5}$

The issue has remained on the UK Green Party's agenda and has been discussed in a scholarly and practical way in the UK since that time. ${ }^{6}$ It is time for it to be discussed more in Australian constitutional circles too, given the continued low numbers of women in the Parliament, and it is a discussion I am sure Deborah would have enjoyed engaging with.

\section{Representations of Women in the Australian Constitutional System}

\section{History Around the Writing of and Impact of the Piece}

Deborah had already begun writing our 1995 article when she approached me to continue working with her on it. Susan Marks wrote in her reflections, 'In Memoriam: Deborah Cass', that Deborah's 'writing was fresh and forthright and full of luminous, funny phrases'. 7 Deborah's attention to the ironic is seen beautifully in the opening of our piece, which she had already designed, with an extract from Sir Owen Dixon's judgment in Re Foreman \& Sons Pty Ltd; Uther v Federal Commissioner of Taxation:

\footnotetext{
5 [2015] EWHC 3958 (Admin) ('Cope').

6 See Sarah Childs, The Good Parliament (Report to UK Parliament, July 2016) <https://www. bristol.ac.uk/media-library/sites/news/2016/july/20\%20Jul\%20Prof\%20Sarah\%20Childs\%20 The\%20Good\%20Parliament\%20report.pdf>. See also Rosa Curling, 'The High Court Case' in Open House? Reflections on the Possibility and Practice of MPs Job-Sharing (Pamphlet, The Fawcett Society, 5 September 2017) 17.

7 See Susan Marks, 'In Memoriam: Deborah Cass' (2014) September LSE Ratio: The Magazine of LSE Law 22, 23.
} 
Like the goddess of wisdom the Commonwealth uno ictu sprang from the brain of its begetters armed and of full stature. ${ }^{8}$

She wrote: 'According to Sir Owen Dixon, the Commonwealth of Australia sprang, like the Goddess Athena, fully armed from the head of the States. Whether or not this is an apt metaphor from a classical perspective' (and here we cited some literature around that metaphor), ${ }^{9}$ we continued:

from the perspective of Australian women, it is a strange choice. Athena is one of the strongest female images of the Western literary tradition. In contrast, Australian women have not been represented with such vigour in Australian constitutional law. They appear rarely as litigants, occasionally as members of Parliament, sometimes as part of the Executive, and virtually never as judicial decision makers. Their presence in the Australian system could never be described as 'armed' or 'of full stature'. To this extent, the ascription of feminine strength to the entity which represented Australian nationhood is at odds with the reality; the historical exclusion of women from the constitutional arena. ${ }^{10}$

As for questions of choice, the idea behind placing our joint article into the Adelaide Law Review was timely and topical. Volume 17, 1995, included articles relevant to commemorating the centenary of the passing of the Constitution Amendment Act 1894 in March 1895. ${ }^{11}$ That Act was the final legal step in extending suffrage to women on equal terms with men in the state of South Australia. Much has been written around those steps and where it fits in the overall history of women's right to vote in the British Empire and internationally, ${ }^{12}$ and it was also important ultimately to the development of section 41 of the Australian Constitution (which expresses a guarantee to the right to vote), given section 41 was inserted thanks to

8 (1947) 74 CLR 508, at 530.

9 Cass and Rubenstein, 'Representations of Women' (n 2 ) 3.

10 Ibid 4, footnotes omitted.

11 See 'Editorial' (1995) 17 Adelaide Law Review 1.

12 This was discussed in the article itself, and since then there has been further work. Dr Clare Wright has also made a film about this period of history, see Utopia Girls (2011)<https://www.clarewright. com.au/broadcaster>, in which she highlights how Adelaide was the first place where women got both the right to vote and to stand for office concurrently. There is some uncertainty about that latter claim, according to the introduction in the Adelaide Law Review where it is stated that up until 1916 when the Parliamentary Qualifications (Women) Bill was passed there was some doubt that women could stand for election despite having the vote. It was not until 1959 that two female candidates endorsed by the Liberal Country League were elected to the South Australian Parliament' ('Editorial' (1995) 17 Adelaide Law Review 1). Interestingly, Catherine Helen Spence stood for election to the 1897 Constitutional Convention, but some argue her failure to get sufficient votes was due to the uncertainty raised by her opponents of her eligibility to stand in a national arena. 
those South Australian women's insistence that they did not want to lose their existing right to vote in the state when they were able to participate in Commonwealth elections after Federation occurred. ${ }^{13}$

Indeed, those women who had been campaigning their representatives to the Convention about the creation of a Commonwealth Constitution inspired me, with Deborah's support, to use the article not only in academic circles (where it was one of the first academic constitutional law pieces that had gender as a central focus) but practically also, and in 1998 I relied on our piece as a trigger to lobby government directly around the proposed 1998 Constitutional Convention.

The Howard Government had determined to hold a Constitutional Convention, 100 years on from the 1898 People's Convention, to discuss whether Australia should become a republic. It had been determined there were to be 152 delegates, drawn from each state and territory. Seventy-six of the delegates were to be elected by a voluntary postal ballot, held after the first 76 were appointed by the federal government.

The campaign I began with Susan Brennan (then Joint President of YWCA (Young Women's Christian Association) Australia and now Senior Counsel at the Victorian Bar) was to ensure that the 1998 Convention, 100 years on from the founding Convention, would involve equal numbers of men and women, given no women had been present at the $1890 \mathrm{~s}$ Convention. Susan and I prepared a petition, which supporters around the country signed electronically, with many women's organisations also distributing it through their memberships and beyond. This was followed by a trip to Canberra to meet personally with Senator Nick Minchin, who had carriage of organising and running the Convention. We also met other members of Parliament. Deborah met us at Parliament House in advance of our meetings (then pregnant with Rosa), and she contributed to our presentation in Senator Minchin's office with her powerful and intellectually striking manner.

One can only imagine how few women might have been appointed without our campaign, for in spite of it, of the 76 appointed delegates, the government appointed 23 women (30 per cent). When the final composition of the complete 1998 Constitutional Convention (following

13 I have written about that separately in my 'Feminist Judgment' in E Arcioni and K Rubenstein, 'R v Pearson; Ex parte Sipka: Feminism and the Franchise' in Heather Douglas et al (eds), Australian Feminist Judgments (Hart Publishing, 2014) 55, doi.org/10.5040/9781474201292.ch-004. 
the postal voting for the other half) ${ }^{14}$ did not represent 'equal' numbers of women (there were ultimately 49 women out of 152 delegates 32 per cent), a concerted effort to involve more women in the discussion around the move to a republic led to the organising of a dedicated Women's Constitutional Convention held in Parliament House itself, on the 29 and 30 January 1998 in advance of the Government's Convention. The slogan for the Women's Convention, highlighted on the website for the event, stated:

One hundred years ago men gathered to draft the Australian Constitution. Now, for the first time, women from all sections of society will have the opportunity to contribute their perspective. ${ }^{15}$

Several women's organisations were instrumental in organising the Women's Convention with a Convening Committee including representatives from Australian Women Lawyers, the Constitutional Centenary Foundation (ACT Chapter), the National Women's Justice Coalition, the Women's Electoral Lobby, Women Into Politics and YWCA of Australia. Over 300 women, including all those appointed or elected to the Government's Convention, together with women as representatives of a range of organisations and individual women (all listed on the archived website ${ }^{16}$ participated, culminating in a communique delivered to the Constitutional Convention ${ }^{17}$ held in Old Parliament House from 2 to 13 February 1998.

14 I was also involved in 'running' as an elected delegate in Victoria on a 'Women's Ticket' supported by the Victorian Women's Trust and a range of women's organisations, to make the point that more women needed to be elected in the elected section to ensure there were equal numbers, given only 30 per cent of the appointed delegates were women. That experience is worthy of its own article and while not being directly elected, I did attend the Convention as an 'adviser' to Misha Schubert who was elected on a Youth Ticket 'Republic4U'. Her biography at the time stated: 'at 24 years old she is the youngest elected delegate to the Constitutional Convention'. Misha is now the CEO of Science \& Technology Australia, see 'STA Board and Executive', Science \& Technology Australia (Web Page) $<$ https://scienceandtechnologyaustralia.org.au/board-and-executive/>.

15 See the archived website from the event at 'Future Directions', Women's Constitutional Convention (Web Page, 1 October 1997) <http://purl.nla.gov.au/nla/pandora/womconv>, archived at: <http://pandora.nla.gov.au/nph-wb/19980901130000/http://www.womensconv.dynamite.com.au/ index.html>.

16 'Attendees', Women's Constitutional Convention (Web Page, 26 May 1998) <http://pandora.nla. gov.au/nph-wb/19980901130000/http://www.womensconv.dynamite.com.au/dels.htm>.

17 'Outcomes', Women's Constitutional Convention (Web Page, 6 April 1998) <http://pandora.nla. gov.au/nph-wb/19980901130000/http://www.womensconv.dynamite.com.au/outcomes.htm>. 
Before the communique was developed, many individuals delivered papers, ${ }^{18}$ including Deborah Cass. Her paper was titled 'The Last Bastion: Does One Woman on the High Court Equal "Gender Balance"?', ${ }^{19}$ and she provocatively began:

Today I want to speak about an issue which is not on the agenda of the Constitutional Convention but which has a more frequent impact upon Australian democratic life than the identity of our head of state. I am talking about the composition of the High Court. I want to suggest to you that the health of the entire Australian constitutional democracy (regardless of whether we become a republic or not) is undermined by gender imbalance at the High Court.

In her paper, Deborah Cass developed an idea that she had stated in a different context in our original piece. In the context of the High Court and appointments she explained:

I want to clarify something. Everything I am about to say operates regardless of whether one thinks that women judges would decide cases in a particular way, which is different to the way men judges decide. The jury is still out on that one. And I am not entirely sure of the answer myself. But what I am saying, is that regardless of whether women judges decide cases differently to men judges, they should be on the High Court. My argument is about equality of representation, nothing else. Women should be there because they comprise over 50 per cent of the population, are active in law, are affected by it, and because the absurdity of the current imbalance is illustrated by the fact that the reverse situation would never be tolerated by men. Imagine six women and one man. The mind boggles. ${ }^{20}$

18 'Programs and Papers', Women's Constitutional Convention (Web Page, 7 April 1998) <http:// pandora.nla.gov.au/nph-wb/19980901130000/http://www.womensconv.dynamite.com.au/program5. htm>.

19 'The Last Bastion: Does One Woman on the High Court Equal "Gender Balance"?', Women's Constitutional Convention (Web Page, 7 April 1998) <http://pandora.nla.gov.au/nph-wb/ 19980901130000/http://www.womensconv.dynamite.com.au/cass.htm>. I might add, that Deborah was 'very' pregnant when she delivered this paper in Parliament House, as she delivered Rosa the following week!

20 This point reminds me of Ruth Bader Ginsburg's answer to the question, How many women should be on the US Supreme court? Ryan Lovelace, 'Ruth Bader Ginsburg: There will be Enough Women on the Supreme Court when there are Nine', The Washington Examiner (online, 12 September 2017) <https://www.washingtonexaminer.com/ruth-bader-ginsburg-there-will-be-enough-women-onthe-supreme-court-when-there-are-nines. 
This is one aspect of our discussion about representation raised in our 1995 article to which I will now turn - does it matter whether women act or represent their electorate 'differently' to men?

\section{Themes of the Piece}

The central focus of our 1995 piecewasaround the concept of representation. It examined women as representatives in government, women as they are represented by government and women in representations of government. The argument in the article was that, in 1995, at the level of doctrine, the High Court was moving to a position that emphasised the participatory aspect of representation, which we argued was consistent with a feminist critique of representative democracy. Our point, which is still important, is that low levels of participation by women undermines the representative nature of that concept. ${ }^{21}$

Moreover, we were of the view that in light of Australia's history and in light of Australia's practice at 1995, Australia's system lagged behind the theoretical insights suggested by feminist argument, and the conclusions which followed from High Court doctrine at that time. Our aim was to demonstrate the need for a synthesis of constitutional practice with theory and doctrine, by suggesting that increased participation of women is essential for Australia's constitutional system to conform with evolving standards of representative democracy. ${ }^{22}$ The piece was structured around the following sections: 'Representative Democracy as a principle which underpins the Australian Constitutional system', 'Representative Democracy and the relevance of gender', 'The representation of women in the Australian Constitutional system', and 'Becoming a more Representative Democracy'. The first section's content, examining representative democracy as seen through the High Court analysis, was framed naturally around the jurisprudence at that point, and since that time, there is more to 'add' and 'subtract' to the Court's views on representative democracy. Some of that newer material was touched upon in my subsequent piece with Christabel Richards Neville, ${ }^{23}$ and is further extended by Katrina Hall in her research in this area. ${ }^{24}$ The points about

21 Cass and Rubenstein, 'Representations of Women' (n 2) 5-6.

22 Ibid.

23 Rubenstein and Neville, 'Australia’s Gendered Constitutional History' (n 4).

24 Katrina Hall, 'A Case For Allowing MP Job-Sharing' (JD Paper, ANU Law School, 2018) on file with the author. 
the relevance of gender are ongoing. One of the significant points in that section that still resonates in so many ways with my thinking about these issues more broadly was first made by our colleague Hilary Charlesworth, in the context of the United Nations (UN):

How or whether women's equal participation in decision making would affect the quality of UN decisions is not yet certain. But whatever the evidence of a distinctive woman's influence in political decision-making, it is at least clear that the realities of women's lives under the present unbalanced system do not contribute in any significant way to the shaping of UN policy. ${ }^{25}$

We continued arguing that:

the central insight suggested by the justification remains compelling, namely that women experience the world differently to men as an undeniable matter of practical reality. Moreover, regardless of how many different voices women may have, it does not mean that men can properly represent those different voices. The personal experience of some women representatives suggests that men cannot listen to women's views. ${ }^{26}$

Sadly, this is still a common problem. ${ }^{27}$

There have also been changes since 1995 to the issues we identified in 'The representation of women in the Australian Constitutional system': on one hand, the growth of women on the High Court has been positive; ${ }^{28}$ on the other, there has not been significant change in relation to the proportion of women in Parliament in those 20-plus

25 Cass and Rubenstein, 'Representations of Women' (n 2) 22, quoting Hilary Charlesworth, 'Transforming the United Men's Club: Feminist Futures of the United Nations' (1994) 4 Transnational Law and Contemporary Problems 420.

26 Cass and Rubenstein, 'Representations of Women' (n 2) 22.

27 This is an issue that is not only related to democratic representation in Parliament, but in society more broadly, as seen through the "me too" campaign' and the need for men to listen to women's experiences.

28 In 2018, there are three women on the High Court bench with the first woman as Chief Justice appointed in January 2017. See 'Susan Kiefel Sworn in as Australia's first Chief Justice of the High Court', $A B C$ News (online, 30 January 2017) <http://www.abc.net.au/news/2017-01-30/susan-kiefel-sworn-inas-first-female-high-court-chief-justice/8222868>. See also my commentary on her appointment, Kim Rubenstein, 'Kiefel Appointment is Refreshing, But Greater Diversity is an Ongoing Task', The Sydney Morning Herald (online, 30 November 2016) <https://www.smh.com.au/opinion/kiefel-appointmentis-refreshing-but-greater-diversity-is-an-ongoing-task-20161129-gt05g4.html>. 
years. ${ }^{29}$ The seesawing that has occurred of women in high office, which reached a high in 2011 when Australia had a woman as Governor-General (Quentin Bryce), Prime Minister (Julia Gillard) and Attorney-General (Nicola Roxon) concurrently, ${ }^{30}$ has ultimately led to the result that within two years, none of those positions were still held by women, and only one woman was a member of Cabinet. ${ }^{31}$ There are also further disappointing examples of the point we made around how women are represented in visual and textual descriptions of aspects of the constitutional process. As we wrote:

historically, representations of women in the Australian constitutional system have been characterised by trivialisation, ambiguity, or complete absence. Women were either not there at all; there in the guise of men in drag; or there to be ridiculed. ${ }^{32}$

The experiences of Julia Gillard as prime minister provide further data to be included as an update to this issue. ${ }^{33}$

Returning to the point of having more women in Parliament to better reflect the diversity of life experiences of the community, it is relevant also to the broader argument and final part of our 1995 article, of how best to become a more representative democracy. For men and women are not, respectively, monolithic groups, and within those groups we need to also acknowledge the diversity of experience that impacts the way we each

29 As at May 2018, female members comprised just under 32 per cent of all parliamentarians at the federal level, and just under 35 per cent in the states and territories. See Anna Hough, 'Composition of Australian Parliaments by Party and Gender: A Quick Guide’ (Research Paper Series 2018-19, Parliamentary Library, Parliament of Australia, 2018) Table 1.

30 A great visual image of women in public office is at 'Women of the New Gillard Ministry', $A B C$ News (online, 14 December 2011) <http://www.abc.net.au/news/2011-12-14/women-of-the-newgillard-ministry/3731528>, showing Julie Collins, Kate Ellis, Nicola Roxon, Julia Gillard, Quentin Bryce, Jenny Macklin and Tanya Plibersek after the swearing in, 2011.

31 See commentary available at Jonathan Pearlman, 'Tony Abbott Under Fire for Having Only One Woman in Cabinet', The Telegraph (online, 16 September 2013) <https://www.telegraph.co.uk/ news/worldnews/australiaandthepacific/australia/10311885/Tony-Abbott-under-fire-for-havingonly-one-woman-in-cabinet.html>.

32 Cass and Rubenstein, 'Representations of Women' (n 2) 42.

33 See Marian Sawer, 'Misogyny and Misrepresentation' (2013) 65(1) Political Science 105, doi.org/ 10.1177/0032318713488316; Marian Woodward, 'Ditch The Witch: Julia Gillard and Gender in Australian Public Discourse' (Honours Thesis, Sydney University, 18 October 2013) <https://ses.library. usyd.edu.au/bitstream/2123/9554/1/Woodward\%2C\%20M_GCST_HonoursThesis_2013.pdf>. 
experience the world. This relates both to gender, and how gender impacts on one's life experience, as well as a range of other factors that influence how each person sees, views and experiences the world. ${ }^{34}$

It is that idea of intersectionality and diversity of experiences that becomes especially relevant to the next section on job-sharing, both in Parliament and beyond. But, to complete this section, which focuses on our joint article as a foundation to the next part of the paper, woven into the actual intellectual underpinning of the piece was the practical fact that we job-shared the writing of that 1995 article. The practice itself reflects an appreciation of shared work as an important and positive step around academic/work 'practice' and about our lived experiences, which is also relevant to becoming a more representative democracy.

My memory is that Deborah approached me to collaborate with her, knowing her own commitments to a balanced workload (she had been successful in receiving some research grants that extended her research work beyond this research), balancing her other academic responsibilities of teaching and university service, together with her personal life (starting a family, as Hannah was born in 1995). This meant she could not and should not have done everything on her own. Moreover, the practice of collaboration meant that we could engage with each other's ideas directly (and I could contribute from my life experience and thinking and research perspective at that point) and from that interaction we came to what I believe was a richer piece than if either of us had written it on our own.

These are principles that also apply to representative democracy and it is around the ideas and value of joint 'shared' work, in a constitutional setting, that I now turn.

34 This is often referred to as 'intersectionality', a term first coined by law professor Kimberlé Crenshaw and her work in the US around gender and race. See 'Kimberlé Crenshaw on Intersectionality, More than Two Decades Later', Columbia Law School (Web Page, 8 June 2017) <https://www.law. columbia.edu/pt-br/news/2017/06/kimberle-crenshaw-intersectionality $>$. The simple point from the idea behind it is that there are many aspects of our life experiences that influence how we engage with issues and how power is exercised, and they may be fluid and context-dependent. 


\section{Job-sharing as a Feminist Constitutional Contribution: The Queen on the application of Sarah Cope and Clare Phipps ${ }^{35}$}

This volume developed from the series of 'evergreen' papers presented at the Centre for International and Public Law conference, 'Traversing Divides - A Symposium in Honour of Deborah Cass', at ANU on 14 August 2015, two years after Deborah's death. In the same year as the conference, on 9 April 2015, Sarah Cope and Clare Phipps had applied to the returning officer for Basingstoke to stand as joint candidates for the UK general election on 7 May 2015. Sarah Cope, a single mother of two young children, was unable to work full-time as she was the principal carer for her children, one of whom has an autistic spectrum disorder. ${ }^{36}$ Clare Phipps could not work full-time due to suffering from idiopathic hypersomnia. ${ }^{37}$ They had determined they wanted to represent the constituency of Basingstoke in a job-sharing arrangement and submitted a nomination paper naming them both as a single candidate for the Green Party. The returning officer determined their nomination was invalid because the particulars of the 'candidate' were not 'as required by law' and the paper not subscribed as required. ${ }^{38}$ Sarah Cope and Clare Phipps were therefore unable to stand for election and the Green Party had no candidate for the Basingstoke constituency. ${ }^{39}$ On application for judicial review of the returning officer's decision, they received a written refusal before renewing their request and seeking an oral hearing of the matter. Their application was ultimately heard before Justice Wilkie at the High Court in London on 28 July 2015.

35 I am grateful for the work of ANU Law student, Katrina Hall, around her graduate research under my supervision linked to this case and her insights on the decision. Her excellent 2018 ANU graduate paper, 'A Case For Allowing MP Job-Sharing', has contributed to my thinking and I have drawn from her descriptions around the case in this section. Her paper also discusses the earlier Scottish case, Secretary of State for Scotland and the Advocate General for Scotland v Mann [2000] EAT/56/00, discussed in Alice Belcher and Andrea Ross, 'The Case for Job-Sharing Elected Representatives' (2001) Edinburgh Law Review 380, 384, doi.org/10.3366/elr.2001.5.3.380.

36 Cope (n 5) [1].

37 This is a chronic condition resulting in her sleeping for approximately 12 hours per day. While the judgment explained the 'reasons' for their application to share, more about their situation is set out in Rosa Curling, 'The High Court Case' (n 6) 17.

38 Cope (n 5) [5].

39 Ibid [5]. 
In that hearing, they applied for a declaration that the returning officer's rejection of their joint nomination was unlawful. Their arguments drew from their rights under the European Convention on Human Rights, including their right to stand for election, ${ }^{40}$ their right to be free from discrimination on the grounds of gender and disability, ${ }^{41}$ and their right to respect for private and family life. ${ }^{42}$ In their view, the refusal was inconsistent with the Convention, and in order to be consistent with the Convention the term 'member' in section 1 of the Parliamentary Constituencies Act 1986 (UK) should be interpreted as including 'two or more members together representing the constituency carrying one vote'. Moreover, they argued the term 'candidate' in schedule 1 of the Representation of the People Act 1983 (UK) should encompass a scenario in which two or more elected candidates would together represent a constituency and carry one vote. ${ }^{43}$ Given section 6(c) of the Interpretation Act 1968 (UK), entitled 'Gender and Number', indicates that 'words in the singular include the plural and words in the plural include the singular', they argued that if that interpretation is not permitted, the Court should make a declaration that the provisions of the 1983 and 1986 Acts are incompatible with the Convention by its powers under section 4 of the Human Rights Act 1998 (UK). ${ }^{44}$ While this latter approach would not affect the validity, operation or enforcement of the laws, ${ }^{45}$ this would then be a trigger for Parliament to then decide whether it wished to amend the law so as to be compatible with the Convention. ${ }^{46}$

Justice Wilkie did not accept their arguments, and determined that the 1983 and 1986 Acts did not permit the nomination of two or more people as representative of single candidate: ${ }^{47}$

[T] he language respectively of schedule 1 of the Representation of the People Act 1983, which sets out Parliamentary election rules, and the Parliamentary Constituencies Act 1986, on the face of it, describe a situation which parliamentary constituencies are represented by a single member and that the arrangements set out

40 Convention for the Protection of Human Rights and Fundamental Freedoms, opened for signature 4 November 1950, 213 UNTS 221 (entered into force 3 September 1953), art 3, protocol 1.

41 Ibid art 14.

42 Ibid art 8; see Cope (n 5) [3], [6].

43 Cope (n 5) [6].

44 Ibid [8].

45 Human Rights Act 1998 (UK) section 4(6).

46 Curling, 'The High Court Case' (n 6) 20.

47 Cope (n 5) [12]. 
in the rules envisage one person standing as a single candidate and, on the face of it, give no more room to there being a job share in which two or more people put themselves forward as a single candidate. ${ }^{48}$

In his view, this conclusion was self-evident on the face of the legislation. ${ }^{49}$ Under section 1(1) of the Parliamentary Constituencies Act 1986 (UK), the Parliament provides:

There shall for the purpose of parliamentary elections by the county and borough constituencies (or in Scotland and the county and borough constituencies), each returning a single member, which are described in Orders in Council made under this Act.

That did not stop him, however, from commenting on the principle of shared representation.

There can be no doubt about the seriousness of the issue or the fact that the job share is, in many fields, a means whereby diversity may be increased in the makeup of particular professions or roles ... In my judgment the issue which the claimants raise is a fundamental one in relation to our parliamentary democracy. ${ }^{50}$

Yet, these were not issues for a judge to grapple with, because they raised

a range of complex practical and conceptual questions with which the court is not remotely equipped to deal with and, in my judgment, insofar as the supposed amendment would require the court to consider those issues as germane to the issue of incompatibility, these are not proper issues for the court to debate and determine..$^{51}$

As a judge, he was concerned that the decision would involve important practical repercussions' which the Court was not equipped to handle, ${ }^{52}$ such as how job-sharing would work in practice regarding voting and provisions that would be made in the event of the death of a member. ${ }^{53}$

48 Ibid

49 Ibid [13].

50 Ibid [26]-[27].

51 Ibid [30].

52 Cope (n 5) [20] (Wilkie J).

53 Ibid [23]. 
The idea that Parliament should take this issue on had been emphasised in the final report of the Speaker's Conference on Parliamentary Representation in 2010, which stated:

Justice requires that there should be a place within the House of Commons for individuals from all sections of society. If anyone is prevented from standing for Parliament by reason of their gender, background, sexual orientation or a perceived disability, this is an injustice. The democratic right to stand for Parliament exists separately from any debate about the intellectual and behavioural merits of [individuals] as parliamentarians. ${ }^{54}$

Justice Wilkie's decision therefore squarely placed the issue back into the hands of the Parliament, ${ }^{55}$ and it has been part of public discourse since, with no concrete changes at this point.

If job-sharing in Parliament is promoted, it could be a straightforward means to 'improve' systems of representative democracy, as hoped for in our 1995 article. For the same reasons raised by Sarah Cope and Clare Phipps, and as outlined further in Sarah Childs' report ${ }^{56}$ and Rosa Curling's analysis, ${ }^{57}$ job-sharing would enhance our system of representative democracy, both in terms of gender but also in terms of a diversity of life experiences of men and women that would be better accommodated through shared work frameworks.

There are various means for thinking through this approach in Australia, and Katrina Hall has outlined some of these in the Australian context. She has argued that the Commonwealth Electoral Act 1918 (Cth) ('Electoral $A c t$ ') could be interpreted to allow joint representation in the Commonwealth Parliament and that this approach is supported by the existing legal frameworks in the Sex Discrimination Act 1984 (Cth) and Fair Work Act 2009 (Cth). She explains that if section 163 of the Electoral Act was interpreted in a manner that would disallow joint nomination for election to Parliament, this would discriminate against women and all potential candidates who are unable to work full-time due to caring

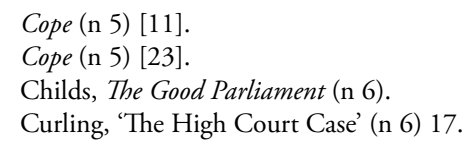


responsibilities or health requirements. ${ }^{58}$ She also makes the argument that an interpretation disallowing joint representation would breach the constitutionally implied freedom of political communication. ${ }^{59}$

Beyond fulfilling the principles of representative democracy, there is also an argument that providing for job-sharing in Parliament would also provide a better foundation and institutional role model to society more broadly. Encouraging job-sharing more universally would enhance not only representative democracy, but the health and wellbeing of the community. This point is made by Professor Jennifer Nedelsky's work with Tom Malleson in their book, Part Time for All. ${ }^{60}$ As Nedelsky and Malleson powerfully argue:

Western societies face three critical problems that arise out of dysfunctional norms of work and care: unsustainable stress on families, persistent inequality for women and others who do care work, and policy makers who are ignorant about the care work that life requires. ${ }^{61}$

Rather than 'allowing' parliamentarians to choose to job share, their proposal in effect mandates it for everyone. Their proposal seeks to ensure that society comes to a position (whether legislatively or through changed norm expectations that would compel it) so that

mature, competent adults are expected to be employed part time (what we now call part-time); no less than between 12 and 30 hours a week, and to do unpaid care work part time - also somewhere between 12 and 30 hours a week. ${ }^{62}$

The arguments in support of this proposal are extensive and significant around several issues, yet there is one argument that is particularly relevant to this article's proposition. Nedelsky and Malleson note, in thinking broadly about problems associated with care management in society, that 'the third problem is the least commented on in the now extensive literature on care'. ${ }^{63}$ They call this 'the policy/care divide'. ${ }^{64}$ This means

58 Hall (n 36).

59 Ibid.

60 Jennifer Nedelsky and Tom Malleson, Part Time for All: A Care Manifesto (Oxford University

Press, forthcoming).

61 Ibid.

62 Ibid.

63 Ibid.

64 Ibid. 
'that those in top policy making positions' (which of course includes lawmakers) 'are almost always people with very little experience of the demands, or satisfactions, or importance of care taking. ${ }^{65}$ In Nedelsky and Malleson's view, this means policymakers on the most part are 'ignorant of a core dimension of human life ${ }^{36}$ rendering them 'unfit for the job' ${ }^{67}$ They further argue:

$$
\begin{aligned}
& \text { we should no more consider electing someone without substantial } \\
& \text { experience in caregiving to public office, or appointing them CEO } \\
& \text { of a corporation, than we would someone who had never held } \\
& \text { a job. }{ }^{68}
\end{aligned}
$$

Their claim is supported by the argument that "knowledge of care is essential to good policy making, and the necessary knowledge can only be acquired by hands-on experience' ${ }^{69}$ In other words, caring for others is relevant and essential to being a good representative in Parliament in fulfilling one's role as a policy and lawmaker. Job-sharing (which may be necessary if more than the 12-30 hours of work are needed for what is recognised as one position), and a responsibility to undertake compulsory care work, is therefore fundamental to a society's fulfilment of representative democracy.

Regardless of whether one is as persuaded as I am by the universal expectation of Nedelsky and Malleson, the central point about policy and representation sits comfortably and powerfully with the concept of shared representation in Parliament, and introducing it and encouraging it would indeed provide a sound role model for job-sharing and could be helpful on the road to the more universal expectation around it, to enhance society more broadly.

\section{Conclusion}

In Deborah and my 1995 article, we identified a range of ideas that had been advocated to improve representation, specifically women's representation:

65 Ibid.

66 Ibid.

67 Ibid.

68 Ibid.

69 Ibid. 
Some aim to alter the composition of parliament and the executive directly. These include: the introduction of voluntary or mandatory gender quotas for the party preselection of candidates, in major political parties; double sex parliamentary representation whereby the size of each electorate would be doubled and each would elect a male and a female representative; the introduction of constitutional quotas guaranteeing a certain percentage of seats to women; and the inclusion in Cabinet of the Minister responsible for women's affairs. A petition presented to a select committee of the New Zealand parliament calls for alteration of electoral legislation to ensure equality and parity of gender representation. Other methods of group representation include the use of functional constituencies in Hong Kong representing groups such as unions and industry within the Legislative Council. Other proposals aim to alter the political and legal culture in which the under-representation has occurred. 'Schooling' in parliamentary skills for women; using the Upper House to 'experiment' with representation for particular groups; reforming parliamentary working hours; and regular government reporting to international review bodies such as the CEDAW [Convention on the Elimination of all Forms of Discrimination Against Women] committee about percentages of women in parliamentary institutions, have all been suggested. ${ }^{70}$

None of those suggestions specifically identified job-sharing - although the idea of each electorate being doubled to elect a male and female representative has a sense of 'shared' representation, although that proposal would lead to two full-time individuals elected to a larger seat. The point behind that proposal, originally identified by the retired member of Parliament Jim Carlton and affirmed by his political adversary Robert Macklin, was, as Macklin wrote in the Canberra Times, not about affirmative action; 'it was about getting a more accurate reflection of society into Parliament'. ${ }^{71}$ Shared representation, which enables an even more accurate reflection of society by including more people- those whose lives do not enable full-time work to be entertained - is another important way of achieving a more accurate reflection of society in Parliament.

70 Cass and Rubenstein, 'Representations of Women' (n 2) 45-46, footnotes omitted.

71 Robert Macklin, 'An Idea Whose Time has Come', Canberra Times (online, 22 October 1993) $11[2]<$ http://nla.gov.au/nla.news-article127513054>. 
Is shared representation an idea we should be thinking about more seriously in Australia, to ensure true democratic representation in our Parliaments, and as a positive constitutional change? Will it be one way to ensuring a more effective and diverse representative body, to better reflect the Australian people? Moreover, might constitutional change also encourage a broader societal change to accepting and encouraging shared work as step towards a commitment legislatively, socially and normatively to the creation of a more balanced, healthy and fairer society (with shared work in many areas) for all?

\section{I think so.}

We will never know for sure, but I feel confident this is an idea that Deborah would have supported. She was certainly my first role model for job-sharing, and both the ideas and the practice have been part of my own scholarship since. Her inspiration for so many of us therefore continues strongly, in many and varied ways. 
This text is taken from Traversing the Divide: Honouring Deborah Cass's Contributions to Public and International Law, edited by Kim Rubenstein, published 2021 by ANU Press, The Australian National University,

Canberra, Australia.

doi.org/10.22459/TD.2021.02 